\title{
Perinatal Case Fatality Rate Related to Congenital Zika Syndrome in Brazil: a Cross-Sectional Study
}

\section{Citation}

Queiroz, Igor Thiago, Jessika Thais Da Silva Maia, Gleysson Rosa, Tatyana Vidal Mendes, S Jayne Alves Vidal, Maria Goretti Lins, Marcelo Rodrigues Zacarkim, David Aronoff, A Desiree Labeaud, and Nilson N Mendes Neto. 2017. "Perinatal Case Fatality Rate Related to Congenital Zika Syndrome in Brazil: a Cross-Sectional Study." Open Forum Infectious Diseases 4 (Suppl 1): S22. doi:10.1093/ofid/ofx162.054. http://dx.doi.org/10.1093/ofid/ofx162.054.

\section{Published Version}

doi:10.1093/ofid/ofx162.054

\section{Permanent link}

http://nrs.harvard.edu/urn-3:HUL.InstRepos:34493202

\section{Terms of Use}

This article was downloaded from Harvard University's DASH repository, and is made available under the terms and conditions applicable to Other Posted Material, as set forth at http:// nrs.harvard.edu/urn-3:HUL.InstRepos:dash.current.terms-of-use\#LAA

\section{Share Your Story}

The Harvard community has made this article openly available.

Please share how this access benefits you. Submit a story.

Accessibility 
944. Perinatal Case Fatality Rate Related to Congenital Zika Syndrome in Brazil: a Cross-Sectional Study

Igor Thiago Queiroz, $\mathrm{MD}, \mathrm{PhD}^{1}$; Jessika Thais Da Silva Maia, $\mathrm{MS}^{2}$; Gleysson Rosa, $\mathrm{RN}, \mathrm{MD}^{3}$; Tatyana Vidal Mendes, $\mathrm{RN}^{4}$; S. Jayne Alves Vidal, $\mathrm{RN}^{5}$; Maria Goretti Lins, $\mathrm{MD}^{6}$; Marcelo Rodrigues Zacarkim, MD, $\mathrm{MS}^{3}$; David Aronoff, MD, FIDSA ${ }^{7}$; . Desiree Labeaud, MD, $\mathrm{MS}^{8}$; Nilson N. Mendes Neto, $\mathrm{MS}^{9} ;{ }^{1}$ Universidade Potiguar, Natal, Brazil; ${ }^{2}$ Universidade Potiguar, Natal - RN, Brazil; ${ }^{3}$ Harvard Medical School, Boston, Massachusetts; ${ }^{4}$ Secretaria Municipal de Saude, Cajazeiras-PB, cajazeiras-PB, Brazil; ${ }^{5}$ SESAP - Rio Grande do Norte, Natal, Brazil; ${ }^{6}$ Hospital Infantil Varela Santiago, Natal, Brazil; ${ }^{7}$ Vanderbilt University School of Medicine, Division of Infectious Diseases, Nashville, Tennessee; ${ }^{8}$ Pediatric Infectious Diseases, Stanford University, Stanford, California; ${ }^{9}$ Extension Center, University of California, Davis, Davis, California

Session: 121. Emerging Paradigms: Pediatric Viral Infections Friday, October 6, 2017: 8:30 AM

Background. Many studies have demonstrated a causal link between Zika virus (ZIKV) infection, microcephaly (MCP), and other congenital abnormalities (CA). This study aimed to determine perinatal case fatality rate in cases of Congenital Zika Syndrome (CZS) in the Rio Grande do Norte State (RN), a Brazilian Northeast State highly impacted by the Zika virus outbreak.

Methods. A cross-sectional study was conducted using data obtained through the State Health Department (SHD) for cases of MCP and CA in Rio Grande do Norte from April 2015 to February 5, 2016. Definition of perinatal period: commences at 22 completed weeks (154 days) of gestation and ends seven completed days after birth.

Results. During the study period, there were 486 cases of MCP and others CA notified in $\mathrm{RN}$, of which 142 were confirmed and 108 remain under investigation. The remaining 236 cases have been ruled out by presenting normal examinations or due to presenting microcephaly by noninfectious causes. Of the total confirmed cases, $26.7 \%$ (38/142) died after birth or during pregnancy. $15.78 \%(06 / 38)$ of confirmed deaths had ZIKV infection during pregnancy and $2.63 \%(01 / 38)$ had a positive TORCH blood test. The six cases related to ZIKV were confirmed by RT-PCR and/or IgM/IgG antibodies against ZIKV. The remaining cases of deaths remain either under investigation or have been ruled out.

Conclusion. This study highlights a high rate of perinatal lethality $(15.78 \%)$ in cases of CZS. Despite the growing number of CZS cases, the real incidence and prevalence might be higher due to the underreporting and lack of resources for confirmatory diagnostic tests (laboratory and imaging). Due to the high rate of lethality and the ongoing uncontrolled ZIKV outbreak, this study predicts an increase in the infant mortality rate in Brazil and highlights the need for developing public health programs to control the ZIKV outbreak.

Disclosures. All authors: No reported disclosures.

945. Fetal and Postnatal Brain Imaging for the Detection of ZIKV Encephalopathy in the Fetus/Newborn

Sarah Mulkey, MD, $\mathrm{PhD}^{1}$; Gilbert Vezina, $\mathrm{MD}^{2}$; Yamil Fourzali, $\mathrm{MD}^{3}$; Dorothy Bulas, $\mathrm{MD}^{2}$; Margarita Arroyave-Wessel, $\mathrm{MPH}^{2}$; Caitlin Cristante, $\mathrm{BS}^{2}$; Christopher Swisher $\mathrm{BS}^{2}$; Youssef Kousa, DO, $\mathrm{PhD}^{2}$; Carlos Cure, $\mathrm{MD}^{4}$; Roberta DeBiasi, MD; MS ; Adre Du Plessis, MBChB, MPH ${ }^{6} ;{ }^{1}$ Fetal Medicine, Children's National Health System, Washington, District of Columbia; ${ }^{2}$ Children's National Health System, Washington, District of Columbia; ${ }^{3}$ Sabbag Radiologos, Barranquilla, Colombia; ${ }^{4}$ BIOMELab, Barranquilla, Colombia; ${ }^{5}$ Pedatrics (Infectious Disesaesand Microbiology, Immunology and Tropical Medicine, Childrens National Health System/GWU School of Medicine, Washington, District of Columbia; ${ }^{6} \mathrm{Fetal}$ Medicine Institute, Children's National Health System, Washington, District of Columbia

Session: 121. Emerging Paradigms: Pediatric Viral Infections Friday, October 6, 2017: 8:30 AM

Background. Up to $15 \%$ of pregnancies complicated by maternal ZIKV infection result in Zika-virus associated brain abnormalities in the fetus/newborn. Fetal ultrasound (feUS) is the standard imaging modality for the evaluation of fetal anatomy and for brain changes from congenital infection. Fetal MRI (feMRI) may be a useful adjunct.

Methods. We performed a prospective longitudinal neuroimaging study of fetuses/newborns of pregnant women with clinical and/or lab confirmed (RT-PCR and/or IgM/PRNT) diagnosis of Zika infection in Barranquilla, Colombia (endemic) and in Washington, DC, USA (travel-related). Gestational age (GA) at exposure and timing between ZIKV exposure/symptoms and imaging was documented. Subjects had one to two feMRIs and feUS, depending upon GA at enrollment. The feMRI and feUS protocols were standardized between sites and studies were centrally interpreted at Children's National. Postnatally, infants received an unsedated brain MRI and head US.

Results. Forty-eight, ZIKV exposed/infected in first or second trimester pregnant women were enrolled (46 Colombia, 2 USA). Subjects had symptoms of ZIKV infection at mean of $8.4 \pm 5.7$ week GA. The first feMRI and feUS were performed at $25.1 \pm 6.3$ week GA. Thirty-six infants had a second feMRI and feUS at $31.1 \pm 4.2$ week GA. Three of $48(6 \%)$ cases had an abnormal feMRI: (1) heterotopias and abnormal cortical indent; (2) parietal encephalocele and Chiari II; (3) thin corpus callosum, dysplastic brainstem, temporal cysts, subependymal heterotopias, and generalized cere$\mathrm{bral} /$ cerebellar atrophy. FeUS in these three cases found (1) normal study; (2) parietal encephalocele and Chiari II; (3) significant ventriculomegaly with decreasing percentiles of head circumference from 32 to 36 week GA ( $38 \%$ to $3.6 \%$ ). Postnatal head US revealed findings not seen on feUS: choroid plexus or germinal matrix cysts in nine infants and lenticulostriate vasculopathy in one infant.
Conclusion. FeMRI and feUS provide complimentary information in the assessment of fetal brain changes in ZIKV. In cases of abnormal brain structure, feMRI reveals more extensive areas of brain damage than is seen by US. Further studies are needed to determine whether cystic changes on postnatal head US are related to ZIKV infection, or are incidental findings.

Disclosures. All authors: No reported disclosures.

946. Maternal Immunization with a Single-Cycle Herpes Simplex Virus (HSV) Candidate Vaccine, $\Delta$ gD-2, Protects Neonatal Mice from Lethal Viral Challenge Carol Kao, $\mathrm{MD}^{1}$; Clare Burn, $\mathrm{MS}^{2}$; William R Jacobs Jr., $\mathrm{PhD}^{2,3}$; Betsy C. Herold, MD FIDSA, FPIDS ${ }^{2,4}$; ${ }^{1}$ Department of Pediatrics, Albert Einstein College of Medicine, Bronx, New York; ${ }^{2}$ Department of Microbiology and Immunology, Albert Einstein College of Medicine, Bronx, New York; ${ }^{3}$ Howard Hughes Medical Institute, Albert Einstein College of Medicine, Bronx, New York; ${ }^{4}$ Department of Pediatrics and Microbiology-Immunology, Albert Einstein College of Medicine, Bronx, New York

Session: 121. Emerging Paradigms: Pediatric Viral Infections

Friday, October 6, 2017: 8:30 AM

Background. Perinatal HSV is associated with $\sim 60 \%$ mortality if untreated and with substantial morbidity even with appropriate therapy. We recently engineered a single-cycle virus deleted in glycoprotein-D $(\Delta \mathrm{gD}-2)$ that induces high-titer antibodies (Abs) that are non-neutralizing but activate the $\mathrm{Fc}$ receptor $(\mathrm{FcR})$ to elicit antibody-dependent cellular cytotoxicity (ADCC). Immunization with $\Delta \mathrm{gD}-2$ completely protects adult mice from HSV-1 and HSV-2 disease following vaginal, skin, intraocular, or intranasal challenge and prevents the establishment of latency (ELife, 2014, JCI Insight, 2016). Thus we hypothesize that maternal immunization with $\Delta \mathrm{gD}-2$ and/or passive transfer of immune serum will protect neonates from HSV.

Methods. Four- to 6 -week-old C57Bl/6 female mice were primed and boosted at 3-week intervals with $\Delta \mathrm{gD}-2$ or an equal volume of uninfected cell lysates (VD60 cells). Two weeks post-boost, mice were mated and pups were challenged with a lethal dose of HSV-1 (Bx31.1) at day 7 of birth. To differentiate the contribution of transplacental vs. colostrum Abs, mothers were switched at birth. Alternatively, 7-day-old mice born to nonimmunized mothers received a single dose of immune serum ( $400 \mu \mathrm{g}$ total $\mathrm{Ab})$ intraperitoneally at time of intranasal challenge.

Results. Thirty-eight of $47(81 \%)$ of the pups born to and nursed by $\Delta \mathrm{gD}-2$ immunized mothers survived, exhibited little or no signs of disease and were protected from latency as measured by quantifying HSV DNA by PCR in neuronal tissue. In contrast, $12 / 14(86 \%)$ of pups born to control vaccinated and nursed mice developed neurological signs of disease and died $(P<0.0001$, Fisher's exact test). Survival was associated with increased ADCC Abs in the serum of neonatal mice. In contrast, passive transfer of immune serum, which consistently protects adult mice from infection, did not protect neonates. If newborns born to immunized mice suckled with control mice, protection was partially abrogated $(11 / 19,58 \%$ survival), suggesting that both systemic and mucosal Abs are required for complete protection.

Conclusion. Maternal vaccination with $\Delta \mathrm{gD}-2$ provides significant protection against intranasal neonatal challenge but may require exposure to systemic and mucosal Abs.

Disclosures. W. R. Jacobs Jr., xvax: Scientific Advisor, Research support; B. C. Herold, X-vax: Grant Investigator, Research grant and Research support

947. Blood Viral Load (VL) Not Clinically Meaningful in Symptomatic Congenital Cytomegalovirus (cCMV) Infection

Concetta Marsico, $\mathrm{MD}^{1}$; Inmaculada $\mathrm{Aban}, \mathrm{PhD}^{2}$; Huichien Kuo, $\mathrm{MS}^{2}$; Pablo J. Sanchez, MD, FIDSA, FPIDS ${ }^{3}$; Amina Ahmed, MD $^{4}$; Ravit Arav-Boger, $\mathrm{MD}^{5}$; Marian Michaels, MD, $\mathrm{MPH}^{6}$; Negar Ashouri, $\mathrm{MD}^{7}$; Janet Englund, MD, FIDSA $^{8}$; Benjamin Estrada, MD, FPIDS ${ }^{9}$; Richard Jacobs, MD, FIDSA, FPIDS ${ }^{10}$; Jose R. Romero, MD ${ }^{11}$; Sunil Sood, MD, FIDSA ${ }^{12}$; Suzanne Whitworth, MD ${ }^{13}$; Scott H. James, $\mathrm{MD}^{14}$; Penny Jester, $\mathrm{RN}^{2}$; Richard Whitley, MD, FIDSA ${ }^{14}$; David W. Kimberlin, MD, FIDSA, FPIDS ${ }^{15}$ and Collaborative Antiviral Study Group (CASG); ${ }^{1}$ University of Bologna, Bologna, Italy; ${ }^{2}$ University of Alabama at Birmingham, Birmingham, Alabama; ${ }^{3}$ Pediatrics, Divisions of Pediatric Infectious Diseases and Neonatology, Nationwide Children's Hospital - Ohio State University College of Medicine, Columbus, Ohio; ${ }^{4}$ Pediatrics, Carolinas Medical Center, Charlotte, North Carolina; ${ }^{5}$ Johns Hopkins, Baltimore, Maryland; ${ }^{6}$ Pediatrics, Children's Hospital of Pittsburgh of UPMC, Pittsburgh, Pennsylvania; ${ }^{7}$ Infectious Diseases, CHOC Children's Hospital, Orange, California; ${ }^{8}$ University of Washington/ Seattle Children's Hospital, Seattle, Washington; ${ }^{9}$ University of South Alabama, Mobile, Alabama; ${ }^{10}$ University of Arkansas, Little Rock, Arkansas; ${ }^{11}$ University of Arkansas for Medical Sciences, Little Rock, Arkansas; ${ }^{12}$ Steven and Alexandra Cohen Children's Medical Center, New Hyde Park, New York; ${ }^{13}$ Cook Children's Medical Center, Fort Worth, Texas; ${ }^{14}$ Pediatrics, Division of Infectious Diseases, University of Alabama at Birmingham, Birmingham, Alabama; ${ }^{15}$ Pediatrics, University of Alabama at Birmingham, Birmingham, Alabama

Session: 121. Emerging Paradigms: Pediatric Viral Infections Friday, October 6, 2017: 8:30 AM

Background. Sensorineural hearing loss (SNHL) and neurodevelopmental (ND) outcomes are favorably impacted by antiviral therapy in infants with symptomatic cCMV disease. We correlated blood VL before and during therapy with clinical findings at presentation and follow-up in this population.

Methods. Post-hoc analysis of two clinical trials conducted by the CASG from 2002 to 2013 evaluating valganciclovir therapy. 120 subjects ( 73 treated $\times 6$ weeks, 47 